DOI: https://doi.org/10.30525/978-9934-26-081-0-4

\title{
ОСОБЛИВОСТІ ТА ПЕРЕВАГИ МІЖНАРОДНИХ КЛАСТЕРІВ
}

\author{
Федотова Ю. В.
}

кандидат економічних наук, дочент, в.о. завідувача кафедри економічної теорії

та міжнародної економіки

Харківського начіонального університету міського господарства

імені О.М. Бекетова

м. Харків, Україна

В економічній літературі можна зустріти дві укрупнені форми, найбільш розповсюджені у світовій практиці господарювання: міждержавна територіальна інтеграція, яка здійснюється за ініціативою державних органів влади та управління; виробнича інтеграція, що здійснюється за ініціативою підприємницьких структур окремих країн. I той, і інший тип інтеграції не виключає виникнення та взаємовпливу комбінованих форм співробітництва.

Закордонний досвід кластеризації свідчить про їх високу ефективність. Інтеграція у кластер створює переваги як для самих суб'єктів кластера, так і для регіональної та національної економіки в цілому.

Як наслідок розвитку міжнародної кооперації, формуються транснаціональні корпорації, що організують виробництво у міжнародному масштабі та регулюють світовий ринок. Особливістю міжнародної інтеграції на сучасному етапі $\epsilon$ виникнення комбінованих форм партнерства у вигляді міжнародних територіальновиробничих кластерів. Останніми десятиліттями внаслідок інтернаціоналізації бізнесу відбувається поступовий розвиток трансграничних кластерних ініціатив, у тому числі між європейськими країнами.

Кластери сприяють активізації інноваційної діяльності, а інновації $\epsilon$ важливим чинником посилення конкурентоспроможності. Це пояснюється наступними чинниками: накопичення у кластерах знань комерційного та виробничого характеру та швидкої дифузії 
знань у кластері; створення інновацій завдяки внутрішній конкуренції між виробниками кластера; пришвидшення впровадження інновацій у результаті співробітництва між постачальниками та виробниками; придбання нововведень у межах міжнародного технологічного співробітництва кластерів.

Згідно одного із підходів до визначення ядра міжнародного інноваційного кластеру [1, с. 9], ядром, як правило, виступає освітня або науково-дослідна установа, що має свою потужну дослідницьку базу, здійснює фундаментальні дослідження та інноваційну діяльність, а також здійснює підготовку або перепідготовку висококваліфікованих кадрів. Іншим прикладом ядра може виступати зацікавлений в активній інноваційній діяльності суб'єкт, який має всі відповідні ресурси для побудови замкненого інноваційного ланцюга, тобто корпорація або підприємство, або їх об’єднання, що мають назву «якірні».

Теоретичні основи кластеризації сьогодні доволі детально визначені у світовій економічній науці. Разом із тим, міжнародна конкуренція та кооперація актуалізують питання дослідження специфіки міжнародних кластерів 3 метою використання їх потенціалу для підвищення конкурентоспроможності країн учасниць інтеграційних об’ єднань.

Міжнародні кластери являють собою:

1) мережеві об’єднання постачальників, виробників та покупців резидентів різних держав, географічно зосереджених у трансграничному регіоні (трансграничний кластер);

2) міжнародні мережі національних кластерів, які співпрацюють та конкурують, пов'язані у технологічні ланцюги та взаємодоповнюють один одного, а також мають взаємозв'язки із трансграничними (у тому числі науковими, освітніми установами, інфраструктурою бізнесу), органами державного та міждержавного управління, а також міжнародними організаціями 3 метою підвищення конкурентоспроможності суб'єктів кластера та національної економіки.

Міжнародні кластери поділяють на трансграничні та транснаціональні [2].

Трансграничний кластер - об’єднання незалежних компаній, суспільних організацій, інших суб’єктів трансграничного співро- 
бітництва, які географічно зосереджені у трансграничному регіону (просторі).

Транснаціональний кластер - сукупність мережі кластерів, які обмінюються частиною результатів НДДКР, використовують мережевий ефект та економію на масштабі для просування продукції на нові ринки.

Можна виділити наступні преваги кластера.

По-перше, кластери сприяють успішному розвитку бізнесу, $\epsilon$ механізмами розвитку інновацій, підприємництва i регіонального розвитку.

По-друге, кластери стимулюють інновації, сприяючи активному інформаційному обміну між учасниками та створюючи стійкі ефекти синергії між взаємодоповнюючими секторами одного виробничого ланцюга.

По-третє, кластери є ключовим інструментом прискорення розвитку підприємництва, що сприяє більш швидкому пошуку ресурсів, знань і технологій, а також ідей, які можуть бути трансформовані у розвиток бізнесу.

По-четверте, кластери складають частину стратегій стимулювання регіонального розвитку та сприяють розвитку економіки знань.

По-п'яте, кластери є центрами розвитку кооперації та конкуренції. У той же час потрібно розуміти, що практично-будь-який кластер це тимчасове явище. Кластери з'являються та зникають залежно від економічної кон'юнктури.

Отже, в якості підсумку можна зазначити, що кластерні структури це якісно новий тип співробітництва між суб'єктами господарювання, у тому числі тих, що належать до різних країн. Однак незважаючи на успішну практику, в Україні кластерні структури досі залишаються поза межами достатньої уваги.

\section{Література:}

1. Кудрявець Є.В. Системоутворювальні ядра міжнародних інноваційних кластерів. Науковий вісник Херсонського державного університету. 2020. Випуск 39. С. 7-14.

2. Яшева Г. Формирование международных кластеров как инструмента системной модернизации трансграничных экономик евразийского содружества. URL: http://du.lv. 